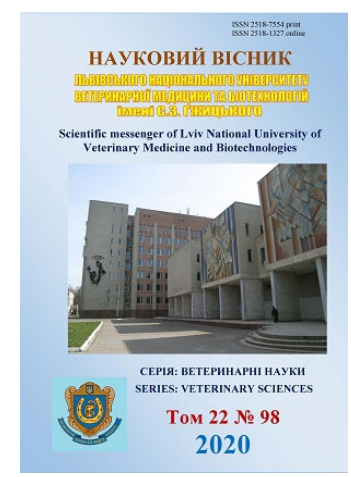

\author{
Науковий вісник Дьвівського національного університету \\ ветеринарної медицини та біотехнологій імені С.3. Гжицького. \\ Серія: Ветеринарні науки \\ Scientific Messenger of Lviv National University \\ of Veterinary Medicine and Biotechnologies. \\ Series: Veterinary sciences
}

\title{
Hygiene-biotic factors on the application of modern pre-and probiotics in poultry
}

\author{
V. P. Lyasota, A. V. Kolodka \\ Bila Tserkva National Agrarian University, Bila Tserkva, Ukraine
}

Article info

Received 06.04.2020

Received in revised form 07.05 .2020

Accepted 08.05.2020

Bila Tserkva National Agrarian University, Soborna pl. 8/1 Bila Tserkva, 09117, Ukraine. Tel.: +38-098-334-63-91 E-mail:Lyasota777@gmail.com, alina19Kolodka@gmail.com
Lyasota, V. P., \& Kolodka, A. V. (2020). Hygiene-biotic factors on the application of modern pre-and probiotics in poultry. Scientific Messenger of Lviv National University of Veterinary Medicine and Biotechnologies. Series: Veterinary sciences, 22(98), 88-93. doi: 10.32718/nvlvet9816

The rapid development of poultry farming requires increasing requirements for the safety and quality of products. This is especially true for broiler chickens, turkeys and meat production. Over the past decade, research by many scientists has shown that fundamental knowledge of the conditions of interaction of the microorganism with the microflora that inhabits biotopes and the creation and widespread introduction into practice of biological products from living or lyophilized microbial cultures - probiotics - is very important. Bacterial preparations based on living microbial cultures - probiotics - have become widespread in the technological process of growing poultry in most countries of the world, including in Ukraine. The microorganisms that make up the probiotic are representative of the normal gut flora; have high antagonistic properties against opportunistic and pathogenic microflora, even those that are insensitive to many antibiotics; have the ability to activate macrophages, ie to influence the intensity of phagocytosis; have the ability to enhance the induction of interferon, ie to influence the increase of factors of natural resistance of animals; to influence the regulation of metabolism in the body of animals, vitamin balance, intestinal digestion; have the ability to produce biologically active substances. To date, studies in the field of bacteriotherapy and prevention of various pathological conditions in animals and poultry associated with disorders of the composition of the normal gut flora are quite relevant. However, in spite of the positive characteristics that pay tribute to probiotic drugs, there are still three areas of concern for improving such drugs in order to achieve their effectiveness in use. First, the microorganisms that make up the probiotic, to a greater or lesser extent, have poor patency through the upper divisions of the digestive canal due to the action of gastric juice and enzymes on them, and therefore do not reach the thick compartment in the amount required to provide required effect. Secondly, if a small number of microorganisms in the composition of the probiotic and has reached the large intestine - it can get bad in the already competitive environment of pathogenic and pathogenic microorganisms already formed during this period. Third, in addition, the use of probiotics inhabits the thick intestine only by the microflora that is part of it and does not reproduce the diversity of its own microflora. The main advantages of probiotics over chemotherapeutic drugs and antitibiotics are that they are harmless to the body of the animal and are environmentally friendly. Due to the great attention to probiotics as environmentally friendly preparations, there is now an increase in the study of biological properties and selection of bacterial strains, the most promising in the probiotic respect. This is the direction of selection of strains specific for the intestinal biocenosis of a particular animal and poultry species, which have high colonization and antagonistic properties. Thus, nowadays, in poultry farming, it is impossible to completely abandon preventive vaccinations, disinfection, use of antibiotics, anthelmintics, coccidiostats and other chemotherapeutic drugs. After their use, the need for enriched diet of pro-and prebiotics increases many times over. This is justified by the need to improve the normal gut microbiota, which, in the first place, leads to increased nutrient uptake of feed and, as a consequence, to improve the nutritional and biological value of poultry products. However, in the current scientific literature, researchers have not sufficiently described the characteristics of the impact on the body of animals, including birds, the above nutraceuticals, also did not determine the quality and safety of slaughter products, did not substantiate their sanitary evaluation. Therefore, the development of new biotic drugs, especially domestic in time.

Key words: intensive technologies, antibiotics, opportunistic pathogenic, pathogenic microflora, probiotics, prebiotics, poultry immunity, quality poultry products, food security. 


\title{
Гігісно-біотичні фактори щодо застосування сучасних пре- і пробіотиків у птахівництві
}

\author{
В. П. Лясота, А. В. Колодка
}

Білочерківський національний аграрний університет, м. Біла Церква, Україна

\begin{abstract}
Продовольча безпека Украӥни зумовлена виробництвом достатньої кількості якісних, екологічно нешкідливих, повноцінних продуктів харчування тваринного походження, серед яких і продукиія птахівниџтва. Впровадження інтенсивних технологій виробництва продукиї̈ птахівництва передбачає застосування різноманітних, екологічно нешкідливих нутріцевтиків, серед яких вітаміни, пробіотики, пребіотики, макро- $і$ мікроелементи, котрі регулюють обмін пуринових основ в організмі, перетворення сульфіту в сульфат, реакиії окислення альдегідів, підсилюють дію вітаміну $C$ - важливого компоненту системи тканинного дихання, а також синтез амінокислот і накопичення азоту в організмі. Іншою загальносвітовою актуальною тенденцією, у зв'язку із забороною використання кормових антибіотиків у процесі відгодівлі тварин, є пошук нових засобів, альтернативних антибіотикам, які б забезпечували ефективніше використання поживних речовин корму, підвищували продуктивність й збереженість птиці, пригнічували умовно-патогенну та знищували патогенну мікрофлору кишечнику, стимулювали імунітет птиці в иілому. Досить ефективними з иього погляду є про- $і$ пребіотики, що рекомендовані для використання, в тому числі й у птахівництві. Проте в сучасній науковій літературі дослідниками недостатньо описані особливості впливу на організм тварин, серед них і птиці, вищезазначених нутрічевтиків, також не визначені показники якості й безпечності продуктів забою, не обтрунтовано їх санітарну оцінку. Тому досліджуване питання є актуальним.
\end{abstract}

Ключові слова: інтенсивні технології, антибіотики, умовно-патогенна, патогенна мікрофлора, пробіотики, пребіотики, імунітет птиці, якісна продукиія птахівництва, продовольча безпека.

\section{Вступ}

Стрімкий розвиток птахівництва потребує підвищення вимог до безпечності та якості продукції. Особливо це стосується вирощування курчат-бройлерів, індиків та отримання м'ясної продукції (Yakubchak et al., 2003; Nitsenko, 2012; Kyryliuk, 2014; Malysheva \& Zavgorodneva, 2014; Makriv, 2015).

За останнє десятиріччя дослідженнями багатьох вчених показано, що досить важливе місце займає фундаментальне пізнання умов взаємодії макроорганізму із мікрофлорою, що населяє біотопи, та створення і широке впровадження у практику біопрепаратів із живих чи ліофілізованих мікробних культур пробіотиків (Stehnii, 2015).

Вагоме місце у технологічному процесі при вирощуванні птахопоголів'я в більшості країн світу, в тому числі в Україні, широкого застосування набули бактеріальні препарати на основі живих мікробних культур - пробіотики.

Мікроорганізми, що входять до складу пробіотиків, $є$ представниками нормальної мікрофлори травного каналу; володіють високими антагоністичними властивостями проти умовно-патогенної та патогенної мікрофлори, навіть такої, що нечутлива до багатьох антибіотиків; мають здатність активізувати макрофаги, тобто впливати на інтенсивність фагоцитозу; володіють властивістю підсилювати індукцію інтерферону, тобто впливати на підвищення чинників природної резистентності тварин; впливати на регуляцію обміну речовин в організмі тварин, вітамінного балансу, кишкового травлення; володіють здатністю до продукування біологічно активних речовин (Pentyliuk, 2015).

На сьогодні досить актуальними є проведення досліджень в галузі бактеріотерапії та профілактики різних патологічних станів у тварин $\mathrm{i}$ птиці, пов'язаних з порушеннями складу нормальної мікрофлори травного каналу (Fotina, 2016).

\section{Результати та їх обговорення}

Нормальна мікрофлора відіграє важливу роль у захисті організму від патогенних мікробів, дії токсичних речовин. Встановлено, що нормальна мікрофлора безпосередньо впливас на формування природної резистентності організму, регулювання процесів метаболізму, вітамінного і мінерального балансу, кишкового травлення, стимулювання імуногенезу. Зміна співвідношення кількісного і якісного складу біоценозу травного каналу в бік переваги умовно-патогенної та патогенної мікрофлори спричиняе порушення метаболізму, гомеостазу організму та викликає порушення нормального фізіологічного стану тварин. Доведено, що найбільш екологічно чисті, нешкідливі, високоефективні засоби корекції мікробіоценозу біопрепарати, виготовлені на основі лактобактерій, кишкових паличок, котрі є природними антагоністами умовно-патогенних та патогенних мікроорганізмів (Bohatko et al., 2011).

31 січня 2006 року у Європейському Союзі введено заборону на використання антибіотиків - стимуляторів росту (Zabarna \& Yakubchak, 2014). В Україні також введені значні обмеження щодо використання антимікробних препаратів у кормах, а також вмісту антибіотиків у продуктах тваринного походження. Так, згідно зі ст. 14 Закону України "Про ветеринарну медицину”, забороняється використання 3 метою прискорення росту і підвищення продуктивності тварин біологічних стимуляторів, антибіотиків, гормональних та інших препаратів. Такі препарати можуть бути застосовані винятково 3 лікувальною метою (Bublyk \& Katerynets, 2011).

Негативний вплив на організм птиці мають і продукти метаболізму антибіотиків, інші ветеринарні препарати, мікроорганізми, токсини, отрути, солі важких металів тощо, котрі надходять 3 ліками та кормами. На ринку ветеринарних препаратів антибіо- 
тики витісняються безпечними та корисними пре- i пробіотиками (Tkachuk \& Palyshniuk, 2014).

Пробіотичні препарати містять штами мікроорганізмів-симбіотів, спеціально підібраних за специфічними бактеріостатичними й ензиматичними властивостями. Завдяки цьому вони здатні створювати бактеріальну рівновагу під час заселення травного тракту та запобігати розвитку там шкідливої мікрофлори. Пробіотичні препарати потрібні також для утворення необхідних для організму тварин метаболітів, ензимів i антитіл. Зовнішнім проявом нормальної бактеріальної рівноваги в організмі тварин є добрий стан здоров'я, хороший апетит, підвищене споживання кормів, швидкий ріст і розвиток. Доведено, що застосування пробіотичних препаратів у тваринництві забезпечує підтримку гомеостазу травного каналу та запобігає розвитку факторних інфекцій у молодняку колібактеріозу, диспепсії та інших, сприяє росту тварин і птиці із високими показниками збереженості (Berhilevych, 2015).

Особливо варто звернути увагу на застосування пробіотиків ослабленим тваринам, коли саме пробіотичні препарати запобігають проникненню умовнопатогенних організмів зі шлунково-кишкового тракту в інші органи і тканини. За даними вчених, після застосування пробіотичних препаратів таким тваринам частота виникнення уражень телят ешерихіями, сальмонелами, стафілококами значно знижувалася (Kovbasenko et al., 2016).

За своїми пробіотичними властивостями найбільш характерними і широко відомими є такі види мікроорганізмів: Bifidobacterium, Lactobacterium, Enterococcus, Bacillus, Streptococcus, Saccharomyces. Розробка наукових основ створення пробіотичних препаратів дала поштовх до їх удосконалення та продовження дослідженнь у цьому напрямку (Binkevych, 2013).

Отже, пробіотики є натуральними, екологічно безпечними препаратами, які містять спеціально підібрані штами мікроорганізмів нормофлори травного тракту та здатні забезпечувати бактеріальну рівновагу під час колонізації шлунково-кишкового тракту, запобігати розвитку шкідливої мікрофлори, сприяти поліпшенню метаболічних процесів в організмі телят та забезпечувати стабільний гомеостаз організму.

Проте, незважаючи на позитивні характеристики, які віддають належне пробіотичним препаратам, усе ж існує три напрямки проблеми щодо удосконалення таких препаратів з метою досягнення їхньої ефективності при застосуванні. По-перше, мікроорганізми, що входять до складу пробіотиків, меншою чи більшою мірою характеризуються поганою прохідністю через верхні відділи травного каналу через дію на них шлункового соку та ферментів, а тому не досягають товстого відділу в тій кількості, котра необхідна, щоб забезпечити необхідний ефект. По-друге, якщо незначна кількість мікроорганізмів зі складу пробіотика i досягла товстого відділу кишечнику - вона може погано приживатися в уже сформованому на цей період конкурентному середовищі з умовно-патогенних та патогенних мікроорганізмів. По-третє, окрім того, застосування пробіотика заселяє товстий відділ кише- чнику лише тією мікрофлорою, що входить до його складу і не відтворює різноманіття власної мікрофлори (Mendel, 2011).

Незважаючи на подану вище інформацію, велика кількість науковців, посилаючись на результати досліджень, стверджують, якщо забезпечити в $1 \mathrm{~cm}^{3}$ (1 г) пробіотика $10^{-6}-10^{-9}$ КУО мікробів-пробіонтів, то вони досить живучі, в достатній кількості надходять до товстого відділу кишечнику та забезпечують терапевтичний ефект, а вищезгадана проблема вирішується за рахунок збільшення концентрації живих мікроорганізмів у складі популяції нормо флори (Mendel, 2009).

Основні переваги пробіотиків перед хіміотерапевтичними препаратами і антибіотиками полягають у тому, що вони нешкідливі для організму тварин та $€$ екологічно чистими. У зв'язку з великою увагою до пробіотиків як екологічно безпечних препаратів нині спостерігається активізація вивчення біологічних властивостей i селекції штамів бактерій, найбільш перспективних у пробіотичному плані. Таким $є$ напрямок з відбору штамів, видоспецифічних для кишкового біоценозу конкретного виду тварин, які мають високу колонізацію й антагоністичну властивість (Klitsenko et al., 2012).

Багаторічний досвід учених і практиків, який базується на традиціях корифеїв медичної та біологічної наук (Л. Пастер, І. Мечников, М. Гамазея й ін.), свідчить про те, що найбільш фізіологічними, екологічно чистими, нешкідливими і водночас високоефективними засобами корекції мікробіоценозу є біопрепарати, виготовлені на основі лактобактерій, кишкових паличок, котрі є природними антагоністами патогенних мікроорганізмів.

У застосуванні їх під час вирощування птиці є багато позитивного, адже основний акцент ставиться на використання та мобілізацію “власних сил організму”, його імунну систему, яка повинна боротися та протистояти бактеріальним і вірусним інфекціям, патогенним грибам,отруєнням тощо (TU U 15.8-35291116008:2009).

Першим запропонував використання живих мікроорганізмів для поліпшення травлення I. I. Мечников. Він виявив, що з віком людини у товстому відділі кишечнику збільшується кількість мікроорганізмів, які володіють протеолітичними властивостями та продукують азотовмісні субстрати з токсичним ефектом. Вчений у 1907 році запропонував замінювати азотовмісні субстрати молочнокислими бактеріями (Biben, 2014).

Узагальнене поняття пробіотик з'явилося в 1965 році. Згодом сформулювали його визначення як живої мікробної кормової добавки, яка справляє корисну дію на тварину-хазяїна шляхом поліпшення кишкового мікробного балансу. В сучасному розумінні термін “пробіотик” був запропонований Річардом і Паркером у 1977 році. Таке визначення мали мікроорганізми та продукти їхньої ферментації, які наділені антагоністичною активністю щодо патогенної мікрофлори (Tereshchenko et al., 2011). 
Від правильного та раціонального вибору про- i пребіотика, які застосовують для відгодівлі птиці та інших тварин, залежить не лише ефективність вирощування, а й споживчі характеристики продуктів їх забою (Mulder, 2015).

Перелік зареєстрованих пробіотиків нараховує близько 80 найменувань вітчизняних та імпортних препаратів (Fisinin, 2016). На сучасному етапі розробки та використання пробіотиків і продуктів на їхній основі насамперед зосереджується увага на тих компонентах, що поліпшують та корегують процеси травлення птиці (розщеплення, всмоктування, засвоєння поживних речовин корму), дії на імунітет через оптимізацію захисної функції організму (Drozdenko, 2010).

Пробіотики змінюють співвідношення корисних i шкідливих мікроорганізмів шлунково-кишкового каналу тварин, а отже регулюють мікробіологічний баланс кишечнику, що дає змогу збільшити середньодобові прирости за рахунок підвищення засвоєння кормів. Введення пробіотиків до раціону тварин, у т. ч. птиці також підвищує життєдіяльність організму, ефективність вакцинацій, сприяє зниженню захворювань, кількості фармакологічних обробок (Meneshian \& Bulkley, 2012).

На відміну від антибіотиків, сучасні пробіотики не спричиняють звикання до патогенної мікрофлори, вони безпечні для навколишнього середовища (Vorbach et al., 2013).

Спектр застосування пробіотиків для годування птиці досить широкий: стимуляція антигеннеспецифічного імунітету, корекції дисбактеріозу у птиці, лікування змішаних шлунково-кишкових захворювань, розладів травлення аліментарної етіології, підвищення ефективності використання корму та продуктивності птахів, зниження контамінації поверхні тушок, для підвищення біологічного ресурсу птиці (Harrison, 2002).

У світовій ветеринарній практиці застосовуються пробіотичні препарати на основі штамів мікроорганізмів. Ряд авторів у своїх роботах наголошують на позитивному впливі зоотехнічних добавок з використанням мікроорганізмів під час годування птиці, зокрема та найчастіше курчат-бройлерів (Gardlik et al., 1987).

Сучасні наукові публікації присвячені з'ясуванню впливу на продуктивність курчат-бройлерів пробіотиків у поєднанні 3 вікасолом, антиоксидантами (Zasiekin et al., 2012), прополісом, цеолітами, сорбентами, глауконітом (Hancock et al., 2002).

Підтверджено доцільність застосування нутріцевтиків цитрату наномолібдену(ЦНМ) і пробіотика "Пробікс" (КД) в бройлерному птахівництві. Доведено позитивний вплив застосованих нутріцевтиків на показники продуктивності, обмінні процеси в організмі курчат та покращення показників якості і збереження безпечності продуктів забою. Додавання до раціону курчат-бройлерів ЦНМ і кормової добавки "Пробікс" приводить до збільшення живої маси проти контролю. Найбільш ефективно на ріст і розвиток птиці впливає самостійне застосування ЦНМ і КД "Пробікс". Застосування курчатам-бройлерам вище- названих нутріцевтиків приводить до вірогідного збільшення забійних показників проти аналогічних показників курчат контрольної групи (Hancock et al., 2002).

Встановлено, що застосування пробіотичного препарату “Олин”, який містить фугати мікробних культур, курчатам-бройлерам підвищує показники резистентності, продуктивності, якості м'яса, нормалізує обмін речовин, стимулює гемопоез (White et al., 1989).

Одночасне застосування молочнокислих бактерій, що входять до складу "Проламу" та Bacillussubtilis 090, що міститься у “Моноспорині”, під час відгодівлі молодняку курей, приводить до стимуляції факторів неспецифічної резистентності, росту, розвитку та збереженості молодняку птиці. Також застосування зазначених пробіотиків приводить до достовірно вищих показників несучості, підвищення м'ясної продуктивності курей (White et al., 1989).

В роботах В. В. Тедтова розглядається пробіотичний препарат “Бифидум СХЖ”, на основі ліфінізованого штаму Bifidobacteriumbifidum і лактози у поєднанні $з$ лецетином, 3 метою поліпшення засвоєння поживних речовин корму, підвищення продуктивності курчат-бройлерів (Aguilar et al., 2017).

Також у періодичній науковій літературі знаходимо результати досліджень дії й інших пробіотиків на організм птиці: “Есід-пак”, “Стрептобіфіда-форте” “Сафманан”, “Біосаф”, “Пробіол-Л” (Mendel \& Kruse, 2012).

Так, “Сафманан” - кормова добавка, що являє собою стінки дріжджових клітин, стимулює ріст, продуктивність та імунітет птиці, при цьому збільшується яйценоскість, підвищуються показники якості яєць, збереженість поголів'я птиці. "Біосаф" - пробіотик, який належить до групи живих дріжджів, стимулює ріст і продуктивність, підвищує імунітет, знижує смертність молодняку птиці (Ratkowsky, 1990).

Застосування пробіотичного препарату "ПробіолЛ” пригнічує ріст патогенних мікроорганізмів, продукує фолієву кислоту, ніацин, вітаміни $\mathrm{B}_{6}, \mathrm{~B}_{12}$, травні ферменти, а також деякі амінокислоти, сприяє підвищенню середньодобових приростів на $10 \%$, живої маси - на 7 \%, зниженню смертності курчат за умов введення в раціон птиці (Grau et al., 1953).

Пребіотики - це відносно нова група кормових добавок, що підсилюють дію пробіотиків, є імуномодуляторами. До пребіотиків належать органічні сполуки малої молекулярної маси - олігосахариди, органічні кислоти, які сприяють розвитку корисних мікроорганізмів і пригнічують дію шкідливих мікроорганізмів. Як і пробіотики, за даними науковців, пребіотики не чинять негативної дії на організм птиці. Встановлено, що пребіотики не розщепляються ферментами макроорганізму і не адсорбуються у передніх відділах травного каналу. Вони є енергетичним субстратом для нормальної мікрофлори кишечнику - біфідобактерій і лактобацил (Connell, 1955).

Так, за результатами досліджень М. Д. Кучерук і G. F. Mathis встановлено, що застосування пребіотика "Біо-Мос" під час вирощування курчат-бройлерів позитивно впливає на збереженість поголів'я та кон- 
версію корму, поліпшує резистентність організму. Застосування пребіотика приводить до підвищення середньодобового приросту курчат і забійного виходу тушок, харчової цінності (Zasiekin et al., 2012).

Застосування рослинно-дріжджового пробіотика "Рекіцен" на основі пшеничних висівок та інактивованих винних дріжджів позитивно впливає на живу масу, збереженість поголів'я, засвоєння поживних речовин, продуктивність і якість м'ясної продукції курчат-бройлерів.

Завдяки специфічній комбінації діючих речовин пребіотик "Агримос" володіє механізмом дії зв'язувати в кишечнику патогенні грамнегативні мікроорганізми та виводити їх з травного тракту, а також стимулює імунну систему птиці. Разом з тим пребіотик сумісний зі всіма компонентами комбікорму, лікарськими засобами та іншими нутріцевтиками та безпечний для споживачів продукції птахівництва. Використання лактулозовмісного пребіотика під час вирощування курчат-бройлерів спричиняє достовірне збільшення живої маси птиці, зниження затрат корму, посилення харчової якості м'яса (Daniel \& Gray, 1953).

\section{Висновки}

Таким чином, нині у птахівництві неможливо зовсім відмовитися від профілактичних щеплень, дезінфекції, використання антибіотиків, антигельмінтиків, кокцидіостатиків та інших хіміотерапевтичних препаратів. Після їх використання необхідність у збагачені раціону про- і пребіотиками збільшується в рази. Це обгрунтовується необхідністю поліпшення нормальної мікрофлори кишечнику птиці, що насамперед спричиняє підвищення засвоєння поживних речовин корму i, як наслідок, поліпшення харчової та біологічної цінності продуктів забою птиці.

Проте в сучасній науковій літературі дослідниками недостатньо описані особливості впливу на організм тварин, у тому числі і птиці, вищезазначених нутріцевтиків, також не визначені показники якості й безпечності продуктів забою, не обгрунтовано їхню санітарну оцінку. Тому розробка нових пробіотичних препаратів, особливо вітчизняних, на часі.

\section{References}

Aguilar, F., Charrondiere, U. R., Dusemund, B. et al. (2017). Potassium molybdate as a source of molybdenum added for nutritional purposes to food supplements. The EFSA Journal, 1136, 1-21. URL: https://efsa.onlinelibrary.wiley.com/doi/pdf/10.2903/j. efsa.2009.1136.

Berhilevych, O. M. (2015). Orhanizatsiia suchasnoho menedzhmentu systemy bezpechnosti kharchovykh produktiv. Mate-rialy II Vseukrainskoi naukovopraktychnoi konferentsii molodykh vchenykh. Ternopil, 179-182 (in Ukrainian).

Biben, I. A. (2014). Immunokorrekcija organizma cypljat kul'turoj probiotika bac. Subtilis BI-12, kak al'ternativa antibiotikoprotekcii. Naukovo-tekhnichnyi biuleten NDTs biobezpeky ta ekolohichnoho kontroliu resursiv APK, 2(3), 68-74. URL: http://nbuv.gov.ua/UJRN/ndbnndc_2014_2_3_13 (in Russian).

Binkevych, V. Ya. (2013). Mikroelementy v hodivli kurchat-broileriv. Eksperymentalna ta klinichna fiziolohiia i bi-okhimiia. Lviv, 2, 150-151 (in Ukrainian).

Bohatko, N. M., Salata, V. Z., \& Holub, O. Iu. (2011). Osoblyvist zastosuvannia systemy NASSR na miasopererobnykh pidpryiemstvakh Ukrainy. Naukovyi visnyk Lvivskoho NUVMBT imeni S. Z. Gzhytskoho, $\quad 11(3(42), \quad 8-12$. URL: https://cyberleninka.ru/article/n/osoblivistzastosuvannya-sistemi-nassr-na-m-yasopererobnihpidpriemstvah-ukrayini (in Ukrainian).

Bublyk, M., \& Katerynets, S. (2011). Analiz vyrobnytstva miasa ptytsi v Ukraini. Ekonomichnyi analiz, 1, 44-47 (in Ukrainian).

Connell, J. J. (1955). Modification of Grau and Hamm's method for the determination of water-binding. Naturwissenschaften, 42(15), 443. doi: 10.1007/BF00599830.

Daniel, L. J., \& Gray, L. F. (1953). Molybdenum toxicity in lactobacillus. Biol. Med., 83(3), 487-490. doi: 10.3181/00379727-83-20392.

Drozdenko, V. M. (2010). Suchasnyi stan ta osoblyvosti rozvytku rynku produktsii ptakhivnytstva v Ukraini Elektronne naukove fakhove vydannia "Efektyvna ekonomika", 6. URL: http://www.economy.nayka. com.ua/?op=1\&z=242 (in Ukrainian).

Fisinin, V. I. (2016). Sovremennye tendencii razvitija rossijskogo i mirovogo pticevodstva. Efektivne ptahivnictvo, 11(23), 8-14 (in Russian).

Fotina, T. I. (2016). Biobezopasnost': zalog zdorov'ja pticy. Efektivne ptahivnictvo, 7, 27-31 (in Russian).

Gardlik, S., Barber, M. J., \& Rajagopalan, K. V. (1987). A molybdopterin-free form of xanthine oxidase. Arch. Biochem. Biophys, 259(2), 363-371. doi: 10.1016/0003-9861(87)90502-9.

Grau, R. Hamm, R., \& Baumann, A. (1953). Über den Einfluß von Calcium-lonen auf die Wasserbindung des zerkleinerten Säugetiermuskels. R. Grau, Naturwissenschaften, 40(20), 535-536. doi: 10.1007/BF00628942.

Hancock, J. T., Salisbury, V., Ovejero-Boglione, M. C., Cherry, R. et al. (2002). Antimicrobial properties of milk: dependence on presence of xanthine oxidase and nitrite. Antimicrob. Agents Chemother, 46(10), 33083310. doi: 10.1128/AAC.46.10.3308-3310.2002.

Harrison, R. (2002). Structure and function of xanthine oxidoreductase: where are we now? Free Radic Biol Med, 33(6), 774-797. doi: 10.1016/S0891-5849(02)00956-5.

Klitsenko, H. T., Kulyk, M. F., Kosenko, M. V., \& Lisovenko, V. T. (2012). Mineralne zhyvlennia tvaryn. Kyiv: Svit (in Ukrainian).

Kovbasenko, V. M., Antoshyna, Ye. V., Harnazhenko, Yu. A., \& Melnyk, P. I. (2016). Metodychni rekomendatsii iz zbilshennia vyrobnytstva produktsii ptakhivnytstva ta pidvyshchennia yii yakosti $\mathrm{v}$ hospodarstvakh pivdnia Ukrainy. Odesa (in Ukrainian). 
Kyryliuk, D. O. (2014). Analiz suchasnoho stanu rynku produktsii ptakhivnytstva v Ukraini. Ekonomika APK, 2, 116-119. URL: http://eapk.org.ua/contents/2014/02/116 (in Ukrainian).

Makriv, H. A. (2015). Derzhavne rehuliuvannia ta tsinova polityka shchodo haluzi ptakhivnytstva. Efektyvne ptakhivnytstvo, 6, 7-10 (in Ukrainian).

Malysheva, E. N., \& Zavgorodneva, O. V. (2014). Faktory povyshenija jeffektivnosti proizvodstva produkcii pticevodstva. Jekonomika sel'skohozjajstvennyh i pererabatyvajushhih predprijatij, 3, 31-35. URL: https://www.rucont.ru/efd/257170 (in Russian).

Mendel, R., \& Kruse, T. (2012). Cell biology of molybdenum in plants and humans. Biochimica et Biophysica Acta, 1823(2), 1568-1579. doi: 10.1016/ j.bbamcr.2012.02.007.

Mendel, R-R. (2009). Cell biology of molybdenum. Biofactors, 35(5), 429-434. doi: 10.1002/biof.55.

Mendel, R-R. (2011). Cell biology of molybdenum in plants. Plant Cell Rep, 30(10), 1787-1797. doi: 10.1007/s00299-011-1100-4.

Meneshian, A., \& Bulkley, G. B. (2012). The physiology of endothelial xanthine oxidase: from urate catabolism to reperfusion injury to inflammatory signal. Microcirculation, 9(3), 161-175. doi: 10.1038/sj.mn.7800136.

Mulder, R. (2015). Razvitie mirovogo pticevodstva i rol' VNAP. Efektivne ptahivnictvo, 6(90), 120-15. URL: https://ptichki.net/publishing/articles/457-razvitiemirovogo-ptitsevodstva-i-rol-vnap (in Russian).

Nitsenko, V. S. (2012). Stan ta perspektyvy rozvytku rynku produktsii ptakhivnytstva $\mathrm{v}$ Ukraini. Visnyk Kharkivskoho natsionalnoho tekhnichnoho universytetu silskoho hospodarstva imeni P. Vasylenka, 125, 196-205 (in Ukrainian).

Pentyliuk, S. I. (2015). Suchasni kormovi biopreparaty. Tvarynnytstvo Ukrainy, 6, 25-26 (in Ukrainian).

Ratkowsky, D. A. (1990). Handbook of nonlinear regression models. New Yorkand Basel.: Marcel Dekker.

Stehnii, B. (2015). Zastosuvannia probiotykiv u tvarynnytstvi. Veterynarna medytsyna Ukrainy, 5, 3941 (in Ukrainian).

Tereshchenko, O. V., Katerynych, O. O., \& Rozhkovskyi, O. V. (2011). Suchasni napriamy rozvytku ptakhivnytstva Ukrainy: stan ta perspektyvy naukovoho zab- ezpechennia haluzi. Efektyvne ptakhivnytstvo, 11(83), 7-12 (in Ukrainian).

Tkachuk, S. A., \& Palyshniuk, K. Yu. (2014). Zastosuvannia preparatu Danofloksatsyn $\mathrm{u}$ likuvalnykh tsiliakh ta yoho vmist $\mathrm{u}$ produktsii tvarynnytstva. Problemy zooinzhenerii ta veterynarnoi medytsyny: zbirnyk naukovykh prats Kharkivskoi derzhav-noi zooveterynarnoi akademii. Kharkiv: RVV KhDZVA, 2014. Vyp. 28, ch. 2.S. 109-111. URL: http://nbuv.gov.ua/UJRN/pzvm_2014_28(2)_24 (in Ukrainian).

TU U 15.8-35291116-008:2009. (2010). Rozchyny vodni karboksylativ. [Chynnyi vid 2010-01-01]. Kyiv: Derzhs-tandart Ukrainy (Natsionalni standarty Ukrainy) (in Ukrainian).

Vorbach, C., Harrison, R., \& Capecchi, M. R. (2013). Xanthine oxidoreductase is central to the evolution and function of the innate immune system. Trends Immunol, 24(9), 512-517. doi: 10.1016/S14714906(03)00237-0.

White, C. L., Cadwalader, T. K., Hoekstra, W. G., \& Pope, A. L. (1989). The metabolism of Seselenomethionine in sheep given supplementary copper and molybdenum. J. Anim. Sci., 67(9), 2400-2408. doi: 10.2527/jas1989.6792400x.

Yakubchak, O. M., Khomenko, V. I., Melnychuk, S. D., \& Tkachuk, S. A. (2003). Vplyv vyrobnychykh protsesiv na osnovni parametry napivfabrykativ pry pererobtsi kurchat-broileriv. Suchasne ptakhivnytstvo, 1, 9-10 (in Ukrainian).

Zabarna, I. V., \& Yakubchak, O. M. (2014). Problemni aspekty doslidzhennia antybakterialnykh preparativ $\mathrm{v}$ produktakh ptakhivnytst-va. Naukovyi visnyk NUBiP Ukrainy. Seriia: Veterynarna medytsyna, yakist i bezpeka produktsii tvarynnytstva, 201, 69-73. URL: http://journals.nubip.edu.ua/index.php/Veterenarna/art icle/view/3618 (in Ukrainian).

Zasiekin, D. A., Shuliak, S. V., \& Kucheruk, M. D. (2012). Vplyv riznykh kontsentratsii koloidnoho sribla na mikrobio-tsenoz tonkoho i tovstoho kyshechnyka u perepeliv porody Faraon. Suchasne ptakhivnytstvo, 22(111), 23 26. URL: http://nbuv.gov.ua/UJRN/Sps_2012_2_9 (in Ukrainian). 